\title{
PPARy as a potential therapeutic target in pulmonary hypertension
}

\author{
Roy L. Sutliff, PhD, \\ Assistant Professor of Medicine, Division of Pulmonary, Allergy and Critical Care Medicine, \\ Atlanta VA Medical Center, 1670 Clairmont Road (151-P), Decatur, GA 30033, USA and Emory \\ University, Atlanta, GA, USA \\ Bum-Yong Kang, PhD, and \\ Division of Pulmonary, Allergy and Critical Care Medicine, Atlanta VA Medical Center, Decatur, \\ GA 30033, USA and Emory University, Atlanta, GA, USA

\section{Michael Hart, MD \\ Division of Pulmonary, Allergy and Critical Care Medicine, Atlanta VA Medical Center, Decatur, GA 30033, USA and Emory University, Atlanta, GA, USA}

\begin{abstract}
Pulmonary hypertension $(\mathrm{PH})$ is a progressive disorder of the pulmonary circulation associated with significant morbidity and mortality. The pathobiology of PH involves a complex series of derangements causing endothelial dysfunction, vasoconstriction and abnormal proliferation of pulmonary vascular wall cells that lead to increases in pulmonary vascular resistance and pressure. Recent evidence indicates that the ligand-activated transcription factor, peroxisome proliferatoractivated receptor gamma (PPAR $\gamma$ ) can have a favorable impact on a variety of pathways involved in the pathogenesis of PH. This review summarizes PPAR $\gamma$ biology and the emerging evidence that therapies designed to activate this receptor may provide novel approaches to the treatment of $\mathrm{PH}$. Mediators of PH that are regulated by PPAR $\gamma$ are reviewed to provide insights into potential mechanisms underlying therapeutic effects of PPAR $\gamma$ ligands in PH.
\end{abstract}

\section{Keywords \\ PPAR $\gamma$; pulmonary hypertension}

\section{Introduction}

Pulmonary hypertension $(\mathrm{PH})$ is a progressive disorder defined by an elevation in mean pulmonary artery (PA) pressure above $25 \mathrm{mmHg}$ at rest that is not associated with elevation of the pulmonary capillary wedge pressure. In 2002, over 15,000 deaths and 260,000 hospital visits were attributed to $\mathrm{PH}$ [Hyduk et al. 2005]. Existing treatments for patients with PH include prostacyclin and its analogs, endothelin receptor antagonists, and phosphodiesterase type 5 inhibitors. Two recent meta-analyses examining the efficacy of these treatments arrived at different conclusions and determined that current therapies either

(c) The Author(s), 2010.

Correspondence to: rsutlif@emory.edu.

Reprints and permissions: http://www.sagepub.co.uk/journalsPermissions.nav

Conflict of interest statement

None declared. 
fail [Macchia et al. 2007] or succeed [Galie et al. 2009] in reducing mortality in PH patients. Regardless of these conflicting results, the prognosis in $\mathrm{PH}$ remains poor, and there remains an urgent need for additional studies to enhance our understanding and treatment of this disorder. This review focuses on peroxisome proliferator-activated receptor gamma $(\operatorname{PPAR} \gamma)$ as a novel target that regulates alterations in gene expression that contribute to increased vascular tone and vascular remodeling in $\mathrm{PH}$.

Excellent reviews of the pathobiology of PH report that constriction of the pulmonary vasculature and abnormal proliferation of pulmonary vascular cells result in remodeling of small arterioles and increasing pulmonary vascular resistance [Hassoun et al. 2009; Morrell et al. 2009; Rabinovitch, 2008]. In the past 30 years, growing interest in the pathogenesis and management of $\mathrm{PH}$ has led to a more refined but still incomplete understanding of $\mathrm{PH}$. For example, until recently, $\mathrm{PH}$ was classified into two main categories: primary and secondary PH. Primary PH was often referred to as familial or idiopathic pulmonary hypertension and considered sporadic in onset, whereas secondary PH was associated with other vascular disorders or chronic diseases [Humbert et al. 2004]. However, since 2003, the classification of $\mathrm{PH}$ has been refined in an attempt to create a more encompassing classification system that would permit investigators to more accurately group patients with similar pathogenesis and pathology for clinical trials [Simonneau et al. 2009] (for a review, see Hoeper [2009]). In the most recent categorization, category I includes pulmonary arterial hypertension (PAH) due to idiopathic or heritable disorders, drug and toxin-induced PAH, PAH associated with connective tissue diseases, HIV infection, portal hypertension, schistosomiasis, or chronic hemolytic anemias, persistent pulmonary hypertension of the newborn, and pulmonary veno-occlusive disease or pulmonary capillary hemangiomatosis. Category II PH results from left-sided heart disease. Category III includes PH associated with hypoxemia or chronic lung disease. Category IV PH results from chronic thrombotic or embolic disease. Finally, category V includes PH associated with disorders such as sarcoidosis, histiocytosis $\mathrm{X}$, lymphangiomatosis or diseases causing compression of the great vessels such as fibrosing mediastinitis. This classification scheme emphasizes not only the diversity of conditions that are associated with PH but also the challenges inherent in identifying pathogenic pathways or mediators common to all of these disorders and in successfully targeting these pathways and mediators for therapeutic advantage. This review focuses on one such potential therapeutic target, peroxisome proliferator-activated receptor gamma $(\operatorname{PPAR} \gamma)$ and the mounting evidence for its role in pulmonary vascular biology.

\section{PPAR biology}

PPARs were originally described in 1990 as ligand-activated transcription factors belonging to the nuclear hormone receptor superfamily that includes retinoic acid receptors, thyroid hormone receptors and steroid receptors [Laudet et al. 1992; Issemann and Green, 1990]. PPARs are ubiquitously expressed throughout the body and are composed of three distinct isotypes: $\alpha, \beta / \delta$ and $\gamma$. These three subclasses possess similar structural and functional features but are distinguished by their tissue distribution, ligand specificity and regulation of unique target genes.

The human PPAR $\gamma$ gene is located at chromosome 3p25 and produces four different PPAR $\gamma$ mRNAs. PPAR $\gamma 1$, PPAR $\gamma 3$ and PPAR $\gamma 4$ encode the same protein and PPAR $\gamma 2$ has an additional 30 amino acids at the $\mathrm{N}$ terminus [Tontonoz et al. 1994]. PPAR $\gamma 1$ is expressed ubiquitously, PPAR $\gamma 2$ is predominantly expressed in adipose tissue, PPAR $\gamma 3$ is expressed in macrophages and white adipose tissue and tissue expression of PPAR $\gamma 4$ has not been determined [Braissant et al. 1996]. Like all other PPAR subtypes, activation of PPAR $\gamma$ complexes is promoted by structurally diverse endogenous and exogenous ligands. Endogenous ligands include linoleic acid, $15 \mathrm{~d}_{-} \mathrm{PGJ}_{2}$, and oxidized lipids such as 15 -HETE, 
9-HODE and 13-HODE [Kota et al. 2005; Forman et al. 1996]. Synthetic ligands for the PPAR $\gamma$ receptor include compounds in the thiazolidinedione (TZD) class of insulin sensitizing drugs such as troglitazone, rosiglitazone, ciglitazone, pioglitazone and englitazone. Troglitazone, rosiglitazone and pioglitazone have been employed clinically in the USA in the management of type 2 diabetes.

Despite promiscuity for activating ligands and broad tissue distribution, the specificity of PPAR $\gamma$-mediated effects occurs through recruitment of ligand-specific populations of coactivators and corepressors [Camp et al. 2000; Kodera et al. 2000; Olefsky and Saltiel, 2000]. Ligands produce conformational changes in the PPAR $\gamma$ receptor. The ligand-induced conformational change allows PPAR $\gamma$ to heterodimerize with retinoid $\mathrm{X}$ receptor (RXR). The PPAR/RXR complex binds to DNA at PPAR response elements (PPREs) located in the promoter region of susceptible genes. The cellular PPAR response is heavily dependent on the recruitment or release of coactivators and corepressors [Zhu et al. 2000; Mizukami and Taniguchi, 1997]. Coactivator proteins either possess or recruit proteins with histone acetyltransferase activity. Acetylation of the histone proteins facilitates RNA polymerase binding by altering chromatin structure thereby facilitating transcription of the target gene [Chen et al. 2006]. PPARs can also repress gene expression through transrepression mechanisms. Potential mechanisms of transrepression that have been reported include: (1) PPAR $\gamma$-stimulated nuclear export and inhibition of p65 and (2) ligand-dependent SUMOylation (small ubiquitin-like modifier) of the PPAR $\gamma$ binding domain which targets PPAR $\gamma$ to nuclear corepressors and prevents their proteosomal degradation and clearance from the promoters of regulated genes [Pascual et al. 2005; Kelly et al. 2004]. In general, transrepression of proinflammatory transcription factors, such as NF- $\kappa$ B and AP-1, is believed to be responsible for many of the anti-inflammatory effects of PPAR $\gamma$. Thus, $\operatorname{PPAR} \gamma$ activation can either stimulate or inhibit the expression of selected genes through several discreet mechanisms.

\section{Role of PPARy in pulmonary hypertension}

PPAR $\gamma$ is normally expressed in many cell types in the lung including those of the pulmonary vascular wall such as endothelial and smooth muscle cells. Mounting evidence suggests that loss of PPAR $\gamma$ expression and function may be associated with PH while stimulating this receptor may attenuate PH. These studies are reviewed here followed by a consideration of the mechanisms by which PPAR $\gamma$ regulates PH. Any data obtained from animal models are subject to a number of limitations that limit their translation to the clinical condition. These limitations of available animal models of PAH have been recently and comprehensively reviewed [Stenmark et al. 2009]. In general, common rodent models of PH caused by stimuli such as hypoxia or monocrotaline fail to induce the proliferative plexogenic arteriopathy seen in patients with severe World Health Organization (WHO) Category I PAH. Despite these limitations, animal models, such as hypoxia-induced PH in mice, have and will continue to provide new insights into the pathobiology and treatment of $\mathrm{PH}$. On the other hand, hypoxia-induced PH in mice likely bears considerably more relevance to pulmonary hypertension in patients with WHO Category III pulmonary hypertension caused by hypoxia secondary to lung disease, sleep apnea, or living at altitude.

\section{Reduced PPARy expression is associated with pulmonary hypertension}

PH is characterized by complex precapillary arteriolar plexiform lesions [Edwards and Edwards, 1977]. Ameshima and coworkers provided the first evidence that PPAR $\gamma$ expression was reduced in lung tissue from patients with severe PH. PPAR $\gamma$ was abundantly expressed in lung tissue from normal patients as well as in lung tissue from patients with chronic obstructive pulmonary disease (COPD), but its expression was reduced or absent in the angiogenic plexiform lesions in lung tissue from patients with PH [Ameshima et al. 
2003]. Furthermore, these investigators demonstrated that PPAR $\gamma$ expression was reduced in pulmonary vascular lesions from a rat model of severe PH. Fluid shear stress also decreased PPAR $\gamma$ expression in ECV304 endothelial cells in vitro. Collectively, these findings suggested that increases in vascular shear stress in the lungs of subjects with PH could reduce PPAR $\gamma$ expression, leading to enhanced cellular proliferation and angiogenesis. The authors concluded that fluid shear stress decreased PPAR $\gamma$ expression in endothelial cells and suggested that reductions in PPAR $\gamma$ could contribute to an abnormal, proliferative, apoptosis-resistant endothelial cell phenotype.

Since this initial report linking reductions in PPAR $\gamma$ to PH, several additional studies have provided evidence to support this association. While PPAR $\gamma$ knockout mice present a seemingly straightforward approach to examine the role of loss of PPAR $\gamma$ function in $\mathrm{PH}$, global deletion of PPAR $\gamma$ results in embryonic lethality [Barak et al. 1999]. This potential limitation has been overcome by employing experimental animals with tissue-targeted deletion of PPAR $\gamma$. For example, Guignabert and coworkers examined mice with targeted deletion of PPAR $\gamma$ in vascular endothelium (ePPAR $\gamma^{-/-}$). ePPAR $\gamma^{-1-}$ mice developed spontaneous $\mathrm{PH}$ with right ventricular hypertrophy and muscularization of small distal pulmonary arteries. When exposed to chronic hypoxia $\left(10 \% \mathrm{O}_{2}\right)$ for 3 weeks, wild-type (WT) and ePPAR $\gamma^{-1-}$ mice developed a similar degree of PH. However, when allowed to recover for 4 weeks in normoxia following exposure to chronic hypoxia, $\mathrm{PH}$ persisted in the ePPAR $\gamma^{-1-}$ compared with WT mice suggesting that reduced endothelial PPAR $\gamma$ signaling is sufficient to cause mild PH and impair recovery from chronic hypoxic exposure [Guignabert et al. 2009]. Similarly, targeted depletion of PPAR $\gamma$ from smooth muscle cells using a CreloxP approach resulted in spontaneous PH in mice [Hansmann et al. 2008b]. Taken together, these reports suggest that reduced PPAR $\gamma$ function in pulmonary vascular wall cells is sufficient to cause $\mathrm{PH}$.

\section{Stimulating PPARY attenuates pulmonary hypertension}

In contrast to studies examining loss of PPAR $\gamma$ function in PH, mounting evidence suggests that stimulating this receptor attenuates PH in several experimental models. For example, Matsuda and coworkers demonstrated that monocrotaline-induced $\mathrm{PH}$ and vascular remodeling in the rat were attenuated by treatment with PPAR $\gamma$ ligands. In this study, PPAR $\gamma$ ligands also inhibited monocrotaline-induced vascular wall thickening and staining for proliferating cell nuclear antigen suggesting that PPAR $\gamma$ ligands suppressed cell proliferation and vascular remodeling in monocrotaline-induced PH in the rat [Matsuda $e t$ al. 2005]. Crossno and colleagues showed that $\mathrm{PH}$ and pulmonary vascular remodeling were increased in Wistar-Kyoto rats exposed to continuous hypobaric hypoxia for 3 weeks and that treatment with rosiglitazone attenuated a number of hypoxia-induced derangements including right ventricular hypertrophy, vascular smooth muscle cell (VSMC) proliferation, collagen and elastin deposition, appearance of c-Kit-positive cells in the adventitia, and matrix metalloproteinase-2 activity [Crossno et al. 2007]. Interestingly, despite therapeutic effects on hypoxic vascular remodeling, rosiglitazone failed to attenuate hypoxia-induced increases in pulmonary artery pressure, an observation attributed to the inability of PPAR $\gamma$ ligands to modulate pathways critical in vasoconstriction such as Rho kinase signaling in this model [Crossno et al. 2007]. In another model of PH, Hansmann and colleagues reported that male $\mathrm{ApoE}^{-/-}$mice, fed high fat diets, developed significant increases in right ventricular systolic pressure, pulmonary vascular remodeling and right ventricular hypertrophy and that PPAR $\gamma$ ligands attenuated PH in this experimental model [Hansmann et al. 2008a, 2007].

Our group recently reported that male $\mathrm{C} 57 \mathrm{Bl} / 6$ mice exposed to chronic hypoxia $\left(10 \% \mathrm{O}_{2}\right)$ for 3 weeks developed PH that was attenuated by treatment with the PPAR $\gamma$ agonist, 
rosiglitazone ( $10 \mathrm{mg} / \mathrm{kg} /$ day by gavage), during the final 10 days of hypoxia exposure [Nisbet et al. 2009]. Rosiglitazone treatment also reduced hypoxia-mediated right ventricular hypertrophy and muscularization of small pulmonary arterioles. From a therapeutic perspective, this study also demonstrated that rosiglitazone could reverse established PH by introducing rosiglitazone treatment only after animals had developed PH [Nisbet et al. 2009]. The mechanisms of these therapeutic effects were attributed to PPAR $\gamma$ mediated reductions in Nox4 expression, oxidative stress, and platelet-derived growth factor (PDGF) signaling in the lung. Collectively these reports indicate that PPAR $\gamma$ ligands attenuated pulmonary vascular remodeling and hypertension caused by a variety of stimuli in experimental models. To better understand the mechanism of action of these PPAR $\gamma$ ligand effects in $\mathrm{PH}$ requires an overview of the pathobiology of $\mathrm{PH}$.

\section{Mechanisms of pulmonary hypertension}

There is general agreement that multiple mechanisms contribute to the development/ progression of $\mathrm{PH}$. These factors include but are not limited to vasoconstrictor/vasodilator imbalance, vascular remodeling and inflammation. The synergism between these factors results in functional and structural changes in the pulmonary vasculature leading to increased pulmonary vascular resistance and the development of PH. Comprehensive reviews of these mechanisms have been published recently [Hassoun et al. 2009; Morrell et al. 2009; Rabinovitch, 2008].

PH patients have reduced levels of vasodilators and increased levels of vasoconstrictors. This imbalance results in increased pulmonary vascular resistance. For example, circulating levels of the vasodilator prostacyclin are decreased in PH [Christman et al. 1992], and nitric oxide (NO)-mediated vasorelaxation is impaired [Giaid and Saleh, 1995]. Conversely, levels of vasoconstrictors such as endothelin-1 [Li et al. 1994] and thromboxane [Christman et al. 1992] are increased in PH patients. Current therapeutic modalities for PAH are generally directed at reducing this imbalance in vaso-constricting and vasodilating mediators. These therapies include agents that restore vasodilator levels (e.g. prostacyclin therapy), agents that enhance vasodilating signaling mechanisms (e.g. the phosphodiesterase 5 inhibitor, sildenafil, which prolongs NO-mediated increases in cGMP), and agents that block vasoconstrictor effects (e.g. endothelin receptor antagonists and calcium channel blockers). These agents may also modulate pulmonary vascular remodeling and the structural changes to the pulmonary vasculature that occur in response to vascular injury or secondarily in response to increased intraluminal pressure. The remodeling of the pulmonary vasculature can reduce the cross-sectional diameter of the pulmonary vasculature and increase pulmonary vascular resistance causing sustained $\mathrm{PH}$. Studies examining the molecular mechanisms underlying pulmonary vascular remodeling have implicated growth factor pathways [Jeffery and Morrell, 2002] as well as matrix remodeling [Novotna and Herget, 2002] in the development and progression of $\mathrm{PH}$.

In addition to vasoconstriction and vascular remodeling, inflammation plays a significant role in the development of $\mathrm{PH}$ [Hassoun et al. 2009]. Inflammatory markers are elevated in $\mathrm{PH}$, and the plexiform lesions that characterize severe $\mathrm{PH}$ are surrounded by inflammatory cells including macrophages, T and B lymphocytes, and dendritic cells [Tuder et al. 1994]. These cells may exacerbate $\mathrm{PH}$ by releasing growth factors, reactive oxygen species and additional cytokines [Tuder and Voelkel, 1998]. Chemokines such as CX3CL1, CCL5 and MCP-1, which recruit inflammatory cells, are elevated in PH patients [Sanchez et al. 2007; Balabanian et al. 2002; Dorfmuller et al. 2002]. Therefore, agents that target these inflammatory pathways may reduce inflammation and vascular dysfunction. 
The participation of these complex mechanisms and diverse mediators in $\mathrm{PH}$ pathogenesis suggest that there are many potential therapeutic targets and that successful therapies in $\mathrm{PH}$ may need to target multiple pathways simultaneously. As reviewed in the following section and Table 1 and summarized in Figure 1, PPAR $\gamma$ may represent a novel target that is capable of favorably regulating a variety of pathways that mediate $\mathrm{PH}$ pathogenesis.

\section{Potential pulmonary hypertension mediators that may be regulated by PPARY}

\section{Nitric oxide}

NO represents a well-studied endothelium-derived mediator that plays a critical role in normal pulmonary vascular physiology. Impaired NO bioavailability contributes to $\mathrm{PH}$ [Steinhorn et al. 2001; Adnot et al. 1991]. Although down-regulation of endothelial nitric oxide synthase (eNOS) has been described in PH in some studies [McQuillan et al. 1994], other reports have found reduced, unchanged, or increased levels of the enzyme [Tuder $\mathrm{et}$ al. 1999; Giaid and Saleh, 1995; Xue and Johns, 1995]. More consistent evidence demonstrates that endothelium-derived, NO-mediated vasodilation is impaired in models of PH [Mehta et al. 1995]. Collectively these studies suggest that post-translational alterations in eNOS regulation and/or enhanced NO degradation rather than reduced eNOS expression are important in PH. Supporting the important contribution of derangements in NO bioavailability in $\mathrm{PH}$, genetic deletion of eNOS enhanced susceptibility to hypoxia-induced PH [Fagan et al. 1999], a defect reversed by adeno-viral-mediated transfection of the pulmonary vasculature with eNOS [Champion et al. 2002]. Furthermore, overexpression of eNOS attenuated hypoxia-induced PH [Ozaki et al. 2001]. In addition, NO inhalation improves pulmonary hemo-dynamics and quality of life in a subset of patients with $\mathrm{PH}$ [Channick et al. 1996], and recent advances in cell-based eNOS gene transfer to the lung have demonstrated that eNOS can reverse established PH in animal models and facilitate restoration of the pulmonary microvasculature [Zhao et al. 2006].

NO is produced constitutively in vascular endothelial cells from the amino acid, L- arginine, by the Type III eNOS isoform. Enzyme activity is largely regulated by (1) the availability of intracellular $\mathrm{Ca}^{2+}$, (2) cofactor availability [Rosenkranz-Weiss et al. 1994], and (3) eNOS post-translational modifications [Fulton et al. 1999; Sessa et al. 1995; Busconi and Michel, 1993] including phosphorylation of specific serine, threonine, and tyrosine residues [Dimmeler et al. 1999; Fulton et al. 1999] and eNOS interaction with other proteins including caveolin [Garcia-Cardena et al. 1998] and heat shock protein 90 (hsp90) [Pritchard et al. 2001]. eNOS phosphorylation [Murata et al. 2004] as well as interactions between eNOS and caveolin [Konduri et al. 2003; Murata et al. 2002] are altered in selected models of PH. Our work demonstrated that PPAR $\gamma$ activation modulates endothelial NO bioavailability [Polikandriotis et al. 2005; Calnek et al. 2003]. Rosiglitazone and the naturally occurring PPAR $\gamma$ ligand, $15 \mathrm{~d}-\mathrm{PGJ}_{2}$, increased endothelial NO release not by increasing eNOS protein levels, but through PPAR $\gamma$-dependent mechanisms involving alterations in post-translational regulatory mechanisms that increase eNOS activity. PPAR $\gamma$ ligands increased endothelial NO release by reducing the inhibitory interaction between eNOS and caveolin, increasing interactions between eNOS and the molecular chaperone, hsp 90, and enhancing phosphorylation of eNOS on serine 1177, all post-translational modifications associated with enhanced eNOS activity.

Once produced, endothelial-derived NO reduces vascular tone [Palmer et al. 1987], reduces platelet activation and aggregation [Azuma et al. 1986], decreases stimulated vascular smooth muscle proliferation [Garg and Hassid, 1989], and impairs leukocyte adherence [Bath et al. 1991]. To exert many of these biological effects, NO must diffuse into the 
vascular wall. Its ability to do so may be limited by local concentrations of superoxide. As a result, NO bioavailability can be regulated not only by the rate of NO formation, but also by the rate of NO degradation. Thus, increased superoxide generation constitutes an important mechanism of NO inactivation and endothelial dysfunction in the vascular wall. Superoxide combines at diffusion-limited rates with $\mathrm{NO}$ forming the potent oxidant, peroxyni-trite, thereby reducing the vascular protective effects of $\mathrm{NO}$ and enhancing oxidative stress. Peroxynitrite also oxidizes the NOS cofactor, tetrahydrobiopterin [Kuzkaya et al. 2003]. Deficiency of tetrahydrobiopterin leads electron flow through eNOS to molecular oxygen rather than arginine, producing superoxide rather than NO, a condition referred to as eNOS uncoupling. Enhanced superoxide production in the vascular wall may, therefore, reduce NO bioavailability through multiple mechanisms.

\section{NADPH oxidases}

NADPH oxidases constitute a major source of superoxide production in the vasculature which has been implicated in $\mathrm{PH}$ and that contributes to endothelial dysfunction and vascular cell proliferation [Bedard and Krause, 2007; Griendling et al. 2000]. Originally described in phagocytic cells, the gp91phox-based oxidase is a multicomponent, membraneassociated, enzyme that catalyzes the one electron reduction of oxygen to superoxide using NADH or NADPH as the electron donor [Griendling et al. 2000]. The classical phagocytic NADPH oxidase is composed of several components or subunits including the membrane bound gp91phox (also known as Nox2) and p22phox subunits as well as the cytosolic p47phox and p67phox subunits which, when stimulated, combine with the small G-protein, rac, and translocate to the membrane to activate the enzyme complex. On the other hand, in nonphagocytic cells, the catalytic moiety of NADPH oxidases is composed of one or more gp91phox (Nox2) homologs, Nox1, 3, 4, 5, Duox1 or Duox2 [Lambeth, 2002]. These Nox homologs associate with the membrane-bound p22phox subunit and are differentially regulated and targeted to distinct subcellular loci suggesting that these oxidases serve unique roles in cell function. Nox 1 and 3 are activated through interactions with rac and the p47phox and p67phox homologs, NOXA1 and NOXO1.

Current evidence indicates that Nox4 expression is increased in hypoxia-induced PH in the mouse and in the pulmonary vasculature of patients with PH [Nisbet et al. 2009; Mittal et al. 2007]. Previous reports have demonstrated that Nox 4 is highly expressed in vascular wall cells including smooth muscle and endothelial cells [Sorescu et al. 2002] where it is constitutively active [Ambasta et al. 2004]. Furthermore, hypoxia increased Nox4 expression and pulmonary artery smooth muscle cell (PASMC) proliferation [Mittal et al. 2007], and Nox4 stimulated the proliferation of endothelial [Chen et al. 2008] and smooth muscle cells [Djordjevic et al. 2005]. We have found that hypoxia stimulates Nox4 expression and cell proliferation in the mouse lung in vivo [Nisbet et al. 2009] and in human pulmonary artery endothelial cell (HPAEC) and human pulmonary artery smooth muscle cell (HPASMC) in vitro. Treatment with rosiglitazone during the last 10 days of hypoxia exposure reduced Nox4 levels and ROS production and attenuated hypoxia-induced PH, right ventricular hypertrophy and vascular remodeling. Similarly, rosiglitazone attenuated hypoxia-induced Nox4 expression and proliferation in HPAEC and HPASMC in vitro. Taken together, these findings suggest that NADPH oxidases are important mediators of cell proliferation and vasoconstriction in PH that can be regulated by PPAR $\gamma$.

While it is clear that increases in Nox 4 mRNA levels increase Nox4 activity [Serrander $e t$ al. 2007], a detailed understanding of Nox4 transcriptional regulation remains to be established, and additional studies will be required to clarify how PPAR $\gamma$ regulates Nox4 expression. Nox4 induction has been reported in response to diverse stimuli including hypoxia in kidney and ischemia in brain [Bedard and Krause, 2007]. In smooth muscle cells, 
activators of Nox4 transcription include urokinase, plasminogen activator, angiotensin II, transforming growth factor beta 1 (TGF- $\beta 1$ ), and tumor necrosis factor alpha (TNF-a) [Lambeth et al. 2007]. In contrast, in endothelial cells, oscillatory shear stress [Sorescu et al. 2004] and PPAR $\gamma$ activation [Hwang et al. 2005] suppress Nox4 mRNA levels. However, few studies have examined regulatory elements in the Nox4 promoter. Only the E2F family of transcription factors has been described to activate the Nox4 promoter [Zhang et al. 2008]. In as yet unpublished studies, we have observed that hypoxia stimulates activation of the Nox 4 promoter in part through NF- $\mathrm{BB}$-mediated signaling and enhanced $\mathrm{p} 65$ binding to the Nox 4 promoter which increased Nox4 expression and activity. Furthermore, treatment with rosiglitazone inhibited hypoxia-induced Nox4 expression and activity, proliferation, and p65-Nox4 promoter interaction (unpublished observations). Based on evidence that Nox4 stimulates smooth muscle [Mittal et al. 2007] and endothelial cell [Chen et al. 2008] proliferation, these findings suggest that activation of PPAR $\gamma$ can attenuate the proliferation of pulmonary vascular wall cells.

\section{Prostacyclin}

Another critical regulator of pulmonary vascular function, the endothelial-derived mediator, pros-tacyclin, is a potent vasodilator that inhibits platelet aggregation and exerts antiinflammatory, antithrombotic, and antiproliferative vascular effects [Olschewski et al. 2004]. Overexpression of prostacyclin synthase protected mice from chronic hypoxiainduced PH [Geraci et al. 1999] whereas prostacyclin-receptor deficient mice were sensitized to hypoxia-induced PH [Hoshikawa et al. 2001]. Decreased prostacyclin synthase expression has been noted in the pulmonary arteries of patients with severe PH compared with normal subjects, and the vascular endothelium was found to be the major site of lung vascular prostacyclin synthase expression [Tuder et al. 1999]. In patients with PH, prostacyclin derivatives decreased urinary isoprostane metabolites, an index of oxidative stress, without altering thromboxane A2 [Robbins et al. 2005]. Currently, augmenting prostaglandin levels constitutes a therapeutic strategy in $\mathrm{PH}$, but the precise cellular mechanisms responsible for prostacyclin-mediated benefits remain to be defined. The classical signaling pathway activated by prostacyclin involves ligation of the G-protein coupled cell surface prostacyclin receptor (IP) which when activated stimulates adenylyl cyclase and increases cellular cAMP content. However, prostacyclin and its analogs can also activate PPAR receptors [Forman et al. 1997] including PPAR $\delta$ [Gupta et al. 2000; Lim and Dey, 2002] and PPAR $\gamma$ [Nemenoff et al. 2008; Falcetti et al. 2007] to mediate biological effects.

Several studies have suggested additional potential relationships between PPAR, prostaglandin metabolism, and vascular disease. For example, inducible cyclooxygenase-2 (COX-2) is expressed in vascular endothelial cells and promotes vascular dysfunction. The ability of PPAR $\gamma$ ligands to inhibit COX-2 induction [Subbaramaiah et al. 2001] suggests potential relationships between PPAR $\gamma$ and altered prostaglandin metabolism in vascular dysfunction. Pioglitazone reduced vascular production of the potent vasoconstrictor, thromboxane, in a fructose-induced rat model of metabolic syndrome suggesting that PPAR $\gamma$ activation can also modulate the relative production of vasodilating and vasoconstricting arachidonic acid metabolites in some models [Peredo et al. 2008]. Rosiglitazone attenuated microparticle-induced vascular dysfunction in mouse aorta by preventing microparticle-induced iNOS and Cox-2 upregulation and the overproduction of NO and prostacyclin, respectively [Tesse et al. 2008]. These reports suggest that PPAR $\gamma$ plays an important role in the production of prostanoids that regulate vascular function. 


\section{Endothelin-1}

The potent vasoconstricting polypeptide, endothelin-1 (ET-1), has been implicated in PH pathogenesis. ET-1 receptors are upregulated in the lung in both animal models [Frasch $e t$ al. 1999; Li et al. 1994] and patients with PH [Giaid and Saleh, 1995]. ET-1, as well as endothelium-derived reactive oxygen species, attenuated NO-dependent pulmonary vasodilation following exposure to chronic hypoxia in isolated rat lungs [Jernigan et al. 2004]. ET-1-induced pulmonary vasoconstriction was markedly reduced by administration of $\mathrm{Cu} / \mathrm{Zn}$ superoxide dismutase and was completely attenuated in gp91phox deficient mice [Liu et al. 2006]. These findings suggest that NADPH oxidase and superoxide play an important role in pulmonary vascular effects of ET-1. Endothelin-1 receptor antagonists have been employed in patients with $\mathrm{PH}$ to improve functional status and other indices of PH related morbidity [Jernigan et al. 2004], further suggesting that ET-1 is an important mediator of pulmonary vascular dysregulation. Emerging evidence in several disease states indicates that PPAR $\gamma$ activation attenuates ET-1 signaling. PPAR ligands inhibited ET-1 secretion by vascular endothelial cells in vitro [Liu et al. 2006; Martin-Nizard et al. 2002; Fukunaga et al. 2001; Delerive et al. 1999]. Similarly in nondiabetic patients with metabolic syndrome, treatment with rosiglitazone reduced several markers of vascular inflammation including plasma levels of ET-1 and improved markers of metabolic control while lowering blood pressure and improving flow-mediated vasodilation [Wang et al. 2006].

PPAR $\gamma$ activation also reduced hypertrophy [Bao et al. 2008] and anti-apoptotic effects [Ehara et al. 2004] caused by ET-1 in cardiac myocytes in vitro through altered nuclear factor of activated T cells (NFAT) signaling. Treatment with PPAR $\gamma$ ligands in several rat models of hypertension reduced ET-1 expression in cardiac [Iglarz et al. 2003b; Sakai et al. 2002] and vascular [Iglarz et al. 2003a] tissues. Collectively, these findings suggest that PPAR $\gamma$ activation can attenuate expression of ET-1 in cardiovascular tissues in response to a variety of stimuli and can attenuate ET-1-mediated signaling in selected models.

\section{PDGF signaling}

PDGF participates in PH pathogenesis. Two genes (A and B) produce three biologically active forms of PDGF protein (AA, AB, and BB) [Fredriksson et al. 2004; Raines, 2004]. These proteins activate one or more PGDF receptors ( $\alpha \alpha, \alpha \beta$, or $\beta \beta$ ) to stimulate cell migration and survival. Ligand binding promotes PDGF receptor tyrosine autophosphorylation and subsequent activation of several downstream signaling pathways including Src, phosphatidylinositol 3 kinase (PI3K), phospholipase $\mathrm{C} \gamma$, and Ras. These signaling pathways are largely activated by recruitment of these enzymes to PDGF-R SH-2 domains. The composition of the downstream signaling pathways activated by PDGF and their integration into specific cellular responses continue to be defined [Tallquist and Kazlauskas, 2004]. Although the expression of PDGF and its receptors is limited in the vascular wall at baseline, several pathological stimuli, including alterations in blood pressure and shear stress, induce peptide and receptor expression [Raines, 2004]. PDGF receptor expression was increased in the lungs of patients with PH, and the PDGF receptor antagonist, imatinib, reversed monocrotaline- or hypoxia-induced PH in rodents and improved pulmonary vascular resistance and exercise capacity in a patient with severe idiopathic PH [Ghofrani et al. 2005; Schermuly et al. 2005; Balasubramaniam et al. 2003]. PPAR $\gamma$ ligands attenuated hypoxia-induced PDGF activation in a mouse model of PH in vivo [Nisbet et al. 2009]. Coupled with reports that NO inhibits PDGF signaling [Failli et al. 2000; Sandirasegarane et al. 2000; Fang et al. 1997] and that PPAR $\gamma$ ligands inhibit PDGFstimulated VSMC migration in vitro [Law et al. 2000; Goetze et al. 1999; Marx et al. 1998], these studies suggest that $\operatorname{PPAR} \gamma$ can regulate important proliferative signaling pathways in experimental $\mathrm{PH}$ including those activated by PDGF. 
PDGF receptor activity can also be regulated by phosphatase and tensin homolog deleted on chromosome 10 (PTEN), a dual specificity phosphatase that dephosphorylates both lipid and protein substrates [Gericke et al. 2006]. PTEN catalyzes the removal of the phosphate moiety from the 3-position of the phosphatidylinositol ring, converting the second messenger, $\mathrm{PI}(3,4,5) \mathrm{P}_{3}$, to $\mathrm{PI}(4,5) \mathrm{P}_{2}$ [Maehama and Dixon, 1998]. PTEN and PI3K thereby have opposing actions on cellular levels of $\mathrm{PI}(3,4,5) \mathrm{P}_{3}$. PTEN also dephosphorylates the PDGF receptor. Because PDGF receptor activation mediates cell proliferation and migration in part through stimulation of PI3K, PTEN can inhibit PDGF signaling both at the receptor and through lowering of $\mathrm{PI}(3,4,5) \mathrm{P}_{3}$ levels thereby lowering the activity of PI3K-related downstream mediators such as the protein kinase B, Akt, which mediates survival, growth, and proliferative signals by inhibiting apoptosis.

PTEN activity is regulated at the transcriptional and post-translational level. At the transcriptional level, pathological stimuli such as ischemia have been shown to reduce PTEN expression and promote hypertrophy and remodeling [Schwartzbauer and Robbins, 2001; Tong et al. 2000]. Limited evidence suggests that NF- $\kappa \mathrm{B}$ activation may lead to suppression of PTEN expression [Wang et al. 2007; Han and Roman, 2006]. On the other hand, the PTEN promoter contains two PPAR response elements, and several studies have demonstrated that PPAR $\gamma$ ligands stimulate PTEN expression [Farrow and Evers, 2003; Patel et al. 2001]. Furthermore, PTEN overexpression reduced VSMC proliferation and migration and inhibited injury-induced vascular remodeling in vivo [Huang et al. 2005; Huang and Kontos, 2002]. PTEN activity is inhibited by ROS which cause reversible oxidation of cysteine residues in the phosphatase active site [Leslie et al. 2003; Lee et al. 2002]. In fact, NADPH oxidase-derived ROS facilitate PDGF signaling by inhibiting PTEN [Kwon et al. 2004]. Based on these reports, we postulated that chronic hypoxia caused sustained PI3K/Akt activation, in part, through the generation of NADPH oxidase-derived ROS that stimulate PDGF and inhibit PTEN signaling pathways. We demonstrated that chronic hypoxia increased PDGF receptor activation and reduced PTEN expression in the lung [Nisbet et al. 2009]. Furthermore, treatment with rosiglitazone attenuated hypoxiainduced PDGF receptor activation and restored PTEN levels in hypoxic mice to levels comparable to control animals. The ability of PPAR $\gamma$ ligands to simultaneously stimulate PTEN expression and lower oxidative stress-induced PTEN inactivation while attenuating PH provides a unique strategy to lower PDGF receptor phosphorylation and activation and reduce cellular $\mathrm{PI}(3,4,5) \mathrm{P}_{3}$ levels. We postulate that these integrated effects contribute to the ability of PPAR $\gamma$ to attenuate pulmonary VSMC proliferation and hypertrophy as well as vascular remodeling caused by chronic hypoxia.

\section{Inflammation}

Numerous studies have suggested that inflammation plays an important role in idiopathic $\mathrm{PAH}$ and in $\mathrm{PH}$ associated with connective tissue disease or human immunodeficiency virus infection [Hassoun et al. 2009]. Inflammatory cells including T and B lymphocytes, macrophages, and dendritic cells have been observed in the vascular lesions of patients with $\mathrm{PH}$. Patients with PH also have increased levels of circulating markers of inflammation [Bakouboula et al. 2008]. Common stimuli of PH such as hypoxia cause inflammatory responses in the pulmonary vasculature [Stenmark et al. 2006], and experimental models associated with inflammation, such as mice with deficiency of the anti-inflammatory adipocytokine, adiponectin, develop PH and vascular remodeling [Medoff et al. 2009; Summer et al. 2009]. These reports suggest that therapies preventing or attenuating inflammation in the pulmonary vasculature could have therapeutic potential in PH. PPAR $\gamma$ is expressed in T cells, macrophages, leukocytes, and dendritic cells, suggesting that its activation could modulate inflammation in the pulmonary vasculature that contributes to the development of PH. Numerous studies have demonstrated that PPAR $\gamma$ ligands attenuate 
inflammation in numerous models [Szanto and Nagy, 2008]. Evidence indicates that PPAR $\gamma$ activation reduces macrophage recruitment and inflammatory mediator production, impairs dendritic cell priming of T cells as well as T lymphocyte proliferation and viability. PPAR $\gamma$ ligands also induce regulatory $\mathrm{T}$ cells which downregulate immune responses [Hontecillas and Bassaganya-Riera, 2007; Wohlfert et al. 2007]. Current evidence indicates that these anti-inflammatory effects of PPAR $\gamma$ are mediated not through transactivation of specific target genes, but rather through physical binding to other proinflammatory transcription factors such as NF- $\mathrm{BB}, \mathrm{AP}-1$, and STAT leading to suppression of their activities. The precise mechanisms of these transrepression effects remain to be completely defined but may involve ligand-dependent SUMOylation of PPAR $\gamma$ which targets the receptor to corepressor complexes on the promoters of inflammatory genes preventing proteosomal degradation of the corepressors and thereby causing inhibition of inflammatory gene expression [Pascual et al. 2005].

\section{Progenitor cell recruitment}

Endothelial progenitor cells (EPCs) are bone-marrow-derived cells that are mobilized into the systemic circulation in response to ischemia or vascular injury [Asahara et al. 1997]. The role of EPC in vascular repair, vascular homeostasis, and formation of new blood vessels continues to be defined [Rosenzweig, 2005]. Clinical trials suggest that EPCs may serve as markers of vascular dysfunction and cardiovascular disease [Werner et al. 2005; Hill et al. 2003]. Because endothelial dysfunction participates in the pathogenesis of PH, EPCs may play a role in pulmonary vascular disease [Sata, 2006]. The endogenous erythropoietin system recruits EPCs to the lung in experimental PH in mice [Satoh et al. 2006]. Furthermore, mesenchymal stem cells overexpressing eNOS [Kanki-Horimoto et al. 2006] or EPCs expressing adrenomedullin attenuated monocrotaline (MCT)-induced PH in rats [Nagaya et al. 2003]. These reports suggest that migration of EPCs to the pulmonary vasculature during experimental $\mathrm{PH}$ can exert beneficial effects. PPAR $\gamma$ agonists facilitate the differentiation of angiogenic progenitor cells into EPCs [Wang et al. 2004]. PPAR $\gamma$ agonists also increased the number and migratory activity of EPC in patients with type 2 diabetes and impaired endothelial function [Pistrosch et al. 2005] and increased EPC migratory activity and reduced EPC apoptosis in mice [Gensch et al. 2007]. Collectively, these reports suggest that PPAR $\gamma$ ligands might stimulate EPC to reduce pulmonary vascular dysfunction and reduce $\mathrm{PH}$.

\section{Pulmonary vascular remodeling}

PH involves remodeling of pulmonary vessels with muscularization of nonmuscular distal arterioles, proliferation and migration of VSMC, and increased production of extracellular matrix proteins including fibronectin, collagen, and elastin [Stenmark et al. 2006; Cowan et al. 2000]. Alterations in matrix composition may be related to increased matrix degradation resulting from an imbalance in the matrix metalloproteinases (MMP)-tissue inhibitor of metalloproteinases (TIMP) system [Lepetit et al. 2005; Frisdal et al. 2001; Himelstein and Koch, 1998] with deposition of collagen, elastin, fibronectin, and tenascin-C [Cowan et al. 2000]. Inhibition of MMPs and elastase prevented the progression and actually induced regression of vascular remodeling in an experimental model of PH [Cowan et al. 2000]. In addition, the elastase inhibitor, elafin, protected mice from chronic hypoxia-induced $\mathrm{PH}$ [Zaidi et al. 2002]. Recent evidence indicates that the PPAR $\gamma$ ligand, rosiglitazone, attenuated and reversed vascular remodeling in rat and mouse models of chronic hypoxiainduced PH [Nisbet et al. 2009; Crossno et al. 2007; Hansmann et al. 2007]. Rosiglitazone decreased collagen production and elastin deposition and increased MMP-2 activity [Crossno et al. 2007]. Treatment with PPAR $\gamma$ ligands has also been associated with attenuation of matrix deposition in disorders other than PH [Hao et al. 2008; Makino et al. 2006; Peng et al. 2006]. Taken together, these reports suggest therapeutic mechanisms of 
PPAR $\gamma$ activation in PH could involve attenuation of matrix deposition and remodeling in the pulmonary vasculature.

\section{Conclusions and future directions}

Abundant evidence suggests that PPAR $\gamma$ is a potential therapeutic target for the treatment of PH. It is important to recognize, however, that many of these studies have been performed in animal models that may not serve as adequate models of human PAH [Stenmark et al. 2009]. In addition, the precise molecular and biochemical mechanisms that promote $\mathrm{PH}$ remain to be defined. The studies reviewed in this article suggest that therapeutic targets such as PPAR $\gamma$, which have the capacity to regulate numerous pathways involved in PH pathogenesis simultaneously merit additional investigation. To fully recognize the therapeutic potential of strategies targeting PPAR $\gamma$, future studies must not only determine the relevant molecular pathways that are altered by $\operatorname{PPAR} \gamma$, but also the cellular site of action of these ligands and their relative dependence on the PPAR $\gamma$ receptor.

The completion of preclinical studies will further inform the consideration of PPAR $\gamma$ as a therapeutic target in PH. The current availability of oral thiazolidinedione PPAR $\gamma$ ligands can facilitate clinical trials examining the efficacy of these drugs in patients with PH. However, evidence supporting successful therapy of PH with existing PPAR $\gamma$ ligands could also stimulate the development of novel pharmacological PPAR $\gamma$ ligands with enhanced therapeutic efficacy and/or reduced side effects. The evidence presented in this review indicates that approaches directed at novel targets in the lung, such as PPAR $\gamma$, have significant potential to promote the development of more effective therapies for $\mathrm{PH}$.

\section{Acknowledgments}

The authors acknowledge grant support from the Research Service of the Atlanta Veterans Affairs Medical Center (to CMH), the National Institutes of Health (R01 DK 074518, to CMH and RLS), and Takeda Pharmaceuticals.

\section{References}

Adnot S, Raffestin B, Eddahibi S, Braquet P, Chabrier PE. Loss of endothelium-dependent relaxant activity in the pulmonary circulation of rats exposed to chronic hypoxia. J Clin Invest. 1991; 87:155-162. [PubMed: 1985092]

Ambasta RK, Kumar P, Griendling KK, Schmidt HH, Busse R, Brandes RP. Direct interaction of the novel Nox proteins with p22phox is required for the formation of a functionally active NADPH oxidase. J Biol Chem. 2004; 279:45935-45941. [PubMed: 15322091]

Ameshima S, Golpon H, Cool CD, Chan D, Vandivier RW, Gardai SJ, et al. Peroxisome proliferatoractivated receptor gamma (PPARgamma) expression is decreased in pulmonary hypertension and affects endothelial cell growth. Circ Res. 2003; 92:1162-1169. [PubMed: 12714563]

Asahara T, Murohara T, Sullivan A, Silver M, van der Zee R, Li T, et al. Isolation of putative progenitor endothelial cells for angiogenesis. Science. 1997; 275:964-967. [PubMed: 9020076]

Azuma H, Ishikawa M, Sekizaki S. Endothelium-dependent inhibition of platelet aggregation. Br J Pharmacol. 1986; 88:411-415. [PubMed: 3089351]

Bakouboula B, Morel O, Faure A, Zobairi F, Jesel L, Trinh A, et al. Procoagulant membrane microparticles correlate with the severity of pulmonary arterial hypertension. Am J Respir Crit Care Med. 2008; 177:536-543. [PubMed: 18006886]

Balabanian K, Foussat A, Dorfmuller P, Durand-Gasselin I, Capel F, Bouchet-Delbos L, et al. CX(3)C chemokine fractalkine in pulmonary arterial hypertension. Am J Respir Crit Care Med. 2002; 165:1419-1425. [PubMed: 12016106]

Balasubramaniam V, Le Cras TD, Ivy DD, Grover TR, Kinsella JP, Abman SH. Role of plateletderived growth factor in vascular remodeling during pulmonary hypertension in the ovine fetus. Am J Physiol Lung Cell Mol Physiol. 2003; 284:L826-L833. [PubMed: 12533438] 
Bao Y, Li R, Jiang J, Cai B, Gao J, Le K, et al. Activation of peroxisome proliferator-activated receptor gamma inhibits endothelin-1-induced cardiac hypertrophy via the calcineurin/NFAT signaling pathway. Mol Cell Biochem. 2008; 317:189-196. [PubMed: 18600431]

Barak Y, Nelson MC, Ong ES, Jones YZ, Ruiz-Lozano P, Chien KR, et al. PPAR gamma is required for placental, cardiac, and adipose tissue development. Mol Cell. 1999; 4:585-595. [PubMed: 10549290]

Bath PM, Hassall DG, Gladwin AM, Palmer RM, Martin JF. Nitric oxide and pros-tacyclin. Divergence of inhibitory effects on monocyte chemotaxis and adhesion to endothelium in vitro. Arterioscler Thromb. 1991; 11:254-260. [PubMed: 1847823]

Bedard K, Krause KH. The NOX family of ROS-generating NADPH oxidases: physiology and pathophysiology. Physiol Rev. 2007; 87:245-313. [PubMed: 17237347]

Braissant O, Foufelle F, Scotto C, Dauca M, Wahli W. Differential expression of peroxisome proliferator-activated receptors (PPARs): tissue distribution of PPAR-alpha, -beta, and -gamma in the adult rat. Endocrinology. 1996; 137:354-366. [PubMed: 8536636]

Busconi L, Michel T. Endothelial nitric oxide synthase. N-terminal myristoylation determines subcellular localization. J Biol Chem. 1993; 268:8410-8413. [PubMed: 7682550]

Calnek DS, Mazzella L, Roser S, Roman J, Hart CM. Peroxisome proliferator-activated receptor gamma ligands increase release of nitric oxide from endothelial cells. Arterioscler Thromb Vasc Biol. 2003; 23:52-57. [PubMed: 12524224]

Camp HS, Li O, Wise SC, Hong YH, Frankowski CL, Shen X, et al. Differential activation of peroxisome proliferator-activated receptor-gamma by troglitazone and rosiglitazone. Diabetes. 2000; 49:539-547. [PubMed: 10871190]

Champion HC, Bivalacqua TJ, Greenberg SS, Giles TD, Hyman AL, Kadowitz PJ. Adenoviral gene transfer of endothelial nitric-oxide synthase (eNOS) partially restores normal pulmonary arterial pressure in eNOS-deficient mice. Proc Natl Acad Sci U S A. 2002; 99:13248-13253. [PubMed: 12237402]

Channick RN, Newhart JW, Johnson FW, Williams PJ, Auger WR, Fedullo PF, et al. Pulsed delivery of inhaled nitric oxide to patients with primary pulmonary hypertension: an ambulatory delivery system and initial clinical tests. Chest. 1996; 109:1545-1549. [PubMed: 8769509]

Chen K, Kirber MT, Xiao H, Yang Y, Keaney JF Jr. Regulation of ROS signal transduction by NADPH oxidase 4 localization. J Cell Biol. 2008; 181:1129-1139. [PubMed: 18573911]

Chen Y, Jimenez AR, Medh JD. Identification and regulation of novel PPAR-gamma splice variants in human THP-1 macrophages. Biochim Biophys Acta. 2006; 1759:32-43. [PubMed: 16542739]

Christman BW, McPherson CD, Newman JH, King GA, Bernard GR, Groves BM, et al. An imbalance between the excretion of thromboxane and prostacyclin metabolites in pulmonary hypertension. $\mathrm{N}$ Engl J Med. 1992; 327:70-75. [PubMed: 1603138]

Cowan KN, Jones PL, Rabinovitch M. Elastase and matrix metalloproteinase inhibitors induce regression, and tenascin-C antisense prevents progression, of vascular disease. J Clin Invest. 2000; 105:21-34. [PubMed: 10619858]

Coyle AT, Kinsella BT. Synthetic per-oxisome proliferator-activated receptor gamma agonists rosiglitazone and troglitazone suppress transcription by promoter 3 of the human thromboxane A2 receptor gene in human erythroleukemia cells. Biochem Pharmacol. 2006; 71:1308-1323. [PubMed: 16499875]

Crossno JT Jr, Garat CV, Reusch JE, Morris KG, Dempsey EC, McMurtry IF, et al. Rosiglitazone attenuates hypoxia-induced pulmonary arterial remodeling. Am J Physiol Lung Cell Mol Physiol. 2007; 292:L885-L897. [PubMed: 17189321]

Delerive P, Martin-Nizard F, Chinetti G, Trottein F, Fruchart JC, Najib J, et al. Peroxisome proliferator-activated receptor activators inhibit thrombin-induced endothelin-1 production in human vascular endothelial cells by inhibiting the activator protein-1 signaling pathway. Circ Res. 1999; 85:394-402. [PubMed: 10473669]

Dimmeler S, Fleming I, Fisslthaler B, Hermann C, Busse R, Zeiher AM. Activation of nitric oxide synthase in endothelial cells by Akt-dependent phosphorylation. Nature. 1999; 399:601-605. [PubMed: 10376603] 
Djordjevic T, BelAiba RS, Bonello S, Pfeilschifter J, Hess J, Gorlach A. Human urotensin II is a novel activator of NADPH oxidase in human pulmonary artery smooth muscle cells. Arterioscler Thromb Vasc Biol. 2005; 25:519-525. [PubMed: 15618545]

Dorfmuller P, Zarka V, Durand-Gasselin I, Monti G, Balabanian K, Garcia G, et al. Chemokine RANTES in severe pulmonary arterial hypertension. Am J Respir Crit Care Med. 2002; 165:534539. [PubMed: 11850348]

Edwards WD, Edwards JE. Clinical primary pulmonary hypertension: three pathologic types. Circulation. 1977; 56:884-888. [PubMed: 912851]

Ehara N, Hasegawa K, Ono K, Kawamura T, Iwai-Kanai E, Morimoto T, et al. Activators of PPARgamma antagonize protection of cardiac myocytes by endothelin-1. Biochem Biophys Res Commun. 2004; 321:345-349. [PubMed: 15358182]

Fagan KA, Fouty BW, Tyler RC, Morris KG Jr, Hepler LK, Sato K, et al. The pulmonary circulation of homozygous or heterozygous eNOS-null mice is hyperresponsive to mild hypoxia. J Clin Invest. 1999; 103:291-299. [PubMed: 9916141]

Failli P, De FR, Caligiuri A, Gentilini A, Romanelli RG, Marra F, et al. Nitrovasodilators inhibit platelet-derived growth factor-induced proliferation and migration of activated human hepatic stellate cells. Gastroenterology. 2000; 119:479-492. [PubMed: 10930383]

Falcetti E, Flavell DM, Staels B, Tinker A, Haworth SG, Clapp LH. IP receptor-dependent activation of PPARgamma by stable pros-tacyclin analogues. Biochem Biophys Res Commun. 2007; 360:821-827. [PubMed: 17624303]

Fang S, Sharma RV, Bhalla RC. Endothelial nitric oxide synthase gene transfer inhibits plateletderived growth factor-BB stimulated focal adhesion kinase and paxillin phosphorylation in vascular smooth muscle cells. Biochem Biophys Res Commun. 1997; 236:706-711. [PubMed: 9245718]

Farrow B, Evers BM. Activation of PPARgamma increases PTEN expression in pancreatic cancer cells. Biochem Biophys Res Commun. 2003; 301:50-53. [PubMed: 12535639]

Forman BM, Chen J, Evans RM. The peroxisome proliferator-activated receptors: ligands and activators. Ann N Y Acad Sci. 1996; 804:266-275. [PubMed: 8993549]

Forman BM, Chen J, Evans RM. Hypolipidemic drugs, polyunsaturated fatty acids, and eicosanoids are ligands for peroxisome proliferator-activated receptors alpha and delta. Proc Natl Acad Sci U S A. 1997; 94:4312-4317. [PubMed: 9113986]

Frasch HF, Marshall C, Marshall BE. Endothelin-1 is elevated in monocrotaline pulmonary hypertension. Am J Physiol. 1999; 276:L304-L310. [PubMed: 9950893]

Fredriksson L, Li H, Eriksson U. The PDGF family: four gene products form five dimeric isoforms. Cytokine Growth Factor Rev. 2004; 15:197-204. [PubMed: 15207811]

Frisdal E, Gest V, Vieillard-Baron A, Levame M, Lepetit H, Eddahibi S, et al. Gelatinase expression in pulmonary arteries during experimental pulmonary hypertension. Eur Respir J. 2001; 18:838-845. [PubMed: 11757635]

Fukunaga Y, Itoh H, Doi K, Tanaka T, Yamashita J, Chun TH, et al. Thiazolidinediones, peroxisome proliferator-activated receptor gamma agonists, regulate endothelial cell growth and secretion of vasoactive peptides. Atherosclerosis. 2001; 158:113-119. [PubMed: 11500181]

Fulton D, Gratton JP, McCabe TJ, Fontana J, Fujio Y, Walsh K, et al. Regulation of endotheliumderived nitric oxide production by the protein kinase Akt. Nature. 1999; 399:597-601. [PubMed: 10376602]

Galie N, Manes A, Negro L, Palazzini M, Bacchi-Reggiani ML, Branzi A. A meta-analysis of randomized controlled trials in pulmonary arterial hypertension. Eur Heart J. 2009; 30:394-403. [PubMed: 19155250]

Garcia-Cardena G, Fan R, Shah V, Sorrentino R, Cirino G, Papapetropoulos A, et al. Dynamic activation of endothelial nitric oxide synthase by Hsp90. Nature. 1998; 392:821-824. [PubMed: 9580552]

Garg UC, Hassid A. Nitric oxide-generating vasodilators and 8-bromo-cyclic guanosine monophosphate inhibit mitogenesis and proliferation of cultured rat vascular smooth muscle cells. J Clin Invest. 1989; 83:1774-1777. [PubMed: 2540223] 
Gensch C, Clever YP, Werner C, Hanhoun M, Bohm M, Laufs U. The PPAR-gamma agonist pioglitazone increases neoangiogenesis and prevents apoptosis of endothelial progenitor cells. Atherosclerosis. 2007; 192:67-74. [PubMed: 16876172]

Geraci MW, Gao B, Shepherd DC, Moore MD, Westcott JY, Fagan KA, et al. Pulmonary prostacyclin synthase overexpression in transgenic mice protects against development of hypoxic pulmonary hypertension. J Clin Invest. 1999; 103:1509-1515. [PubMed: 10359560]

Gericke A, Munson M, Ross AH. Regulation of the PTEN phosphatase. Gene. 2006; 374:1-9. [PubMed: 16675164]

Ghofrani HA, Seeger W, Grimminger F. Imatinib for the treatment of pulmonary arterial hypertension. N Engl J Med. 2005; 353:1412-1413. [PubMed: 16192491]

Giaid A, Saleh D. Reduced expression of endothelial nitric oxide synthase in the lungs of patients with pulmonary hypertension. N Engl J Med. 1995; 333:214-221. [PubMed: 7540722]

Goetze S, Xi XP, Kawano H, Gotlibowski T, Fleck E, Hsueh WA, et al. PPAR gamma-ligands inhibit migration mediated by multiple chemoattractants in vascular smooth muscle cells. J Cardiovasc Pharmacol. 1999; 33:798-806. [PubMed: 10226869]

Griendling KK, Sorescu D, Ushio-Fukai M. NAD(P)H oxidase: role in cardiovascular biology and disease. Circ Res. 2000; 86:494-501. [PubMed: 10720409]

Guignabert C, Alvira CM, Alastalo TP, Sawada H, Hansmann G, Zhao M, et al. Tie2-mediated loss of peroxisome proliferator-activated receptor- $\{$ gamma $\}$ in mice causes PDGF-receptor $\{$ beta $\}$ dependant pulmonary arterial muscularization. Am J Physiol Lung Cell Mol Physiol. 2009; 297(6):L1082-L1090. [PubMed: 19801450]

Gupta RA, Tan J, Krause WF, Geraci MW, Willson TM, Dey SK, et al. Prostacyclin-mediated activation of peroxisome proliferator-activated receptor delta in colorectal cancer. Proc Natl Acad Sci U S A. 2000; 97:13275-13280. [PubMed: 11087869]

Han SW, Roman J. Fibronectin induces cell proliferation and inhibits apoptosis in human bronchial epithelial cells: pro-oncogenic effects mediated by PI3-kinase and NF-kappa B. Oncogene. 2006; 25:4341-4349. [PubMed: 16518410]

Hansmann G, de Jesus Perez VA, Alastalo TP, Alvira CM, Guignabert C, Bekker JM, et al. An antiproliferative BMP-2/PPARgamma/apoE axis in human and murine SMCs and its role in pulmonary hypertension. J Clin Invest. 2008a; 118:1846-1857. [PubMed: 18382765]

Hansmann G, Wagner RA, Schellong S, Perez VA, Urashima T, Wang L, et al. Pulmonary arterial hypertension is linked to insulin resistance and reversed by peroxisome proliferator-activated receptor-gamma activation. Circulation. 2007; 115:1275-1284. [PubMed: 17339547]

Hansmann L, Groeger S, von Wulffen W, Bein G, Hackstein H. Human monocytes represent a competitive source of interferon-alpha in peripheral blood. Clin Immunol. 2008b; 127:252-264. [PubMed: 18342575]

Hao GH, Niu XL, Gao DF, Wei J, Wang NP. Agonists at PPAR-gamma suppress angiotensin IIinduced production of plasminogen activator inhibitor-1 and extracellular matrix in rat cardiac fibroblasts. Br J Pharmacol. 2008; 153:1409-1419. [PubMed: 18278065]

Hassoun PM, Mouthon L, Barbera JA, Eddahibi S, Flores SC, Grimminger F, et al. Inflammation, growth factors, and pulmonary vascular remodeling. J Am Coll Cardiol. 2009; 54(1 Suppl):S10 S19. [PubMed: 19555853]

Hill JM, Zalos G, Halcox JP, Schenke WH, Waclawiw MA, Quyyumi AA, et al. Circulating endothelial progenitor cells, vascular function, and cardiovascular risk. N Engl J Med. 2003; 348:593-600. [PubMed: 12584367]

Himelstein BP, Koch CJ. Studies of type IV collagenase regulation by hypoxia. Cancer Lett. 1998; 124:127-133. [PubMed: 9500201]

Hoeper MM. The new definition of pulmonary hypertension. Eur Respir J. 2009; 34:790-791. [PubMed: 19797667]

Hontecillas R, Bassaganya-Riera J. Peroxisome proliferator-activated receptor gamma is required for regulatory CD4+ T cell-mediated protection against colitis. J Immunol. 2007; 178:2940-2949. [PubMed: 17312139] 
Hoshikawa Y, Voelkel NF, Gesell TL, Moore MD, Morris KG, Alger LA, et al. Prostacyclin receptordependent modulation of pulmonary vascular remodeling. Am J Respir Crit Care Med. 2001; 164:314-318. [PubMed: 11463607]

Huang J, Kontos CD. Inhibition of vascular smooth muscle cell proliferation, migration, and survival by the tumor suppressor protein PTEN. Arterioscler Thromb Vasc Biol. 2002; 22:745-751. [PubMed: 12006385]

Huang J, Niu XL, Pippen AM, Annex BH, Kontos CD. Adenovirus-mediated intraarterial delivery of PTEN inhibits neointimal hyperplasia. Arterioscler Thromb Vasc Biol. 2005; 25:354-358. [PubMed: 15569824]

Humbert M, Morrell NW, Archer SL, Stenmark KR, MacLean MR, Lang IM, et al. Cellular and molecular pathobiology of pulmonary arterial hypertension. J Am Coll Cardiol. 2004; 43(12 Suppl S):13S-24S. [PubMed: 15194174]

Hwang J, Kleinhenz DJ, Lassegue B, Griendling KK, Dikalov S, Hart CM. Peroxisome proliferatoractivated receptor-gamma ligands regulate endothelial membrane superoxide production. Am J Physiol Cell Physiol. 2005; 288:C899-C905. [PubMed: 15590897]

Hyduk A, Croft JB, Ayala C, Zheng K, Zheng ZJ, Mensah GA. Pulmonary hypertension surveillance —United States, 1980-2002. MMWR Surveill Summ. 2005; 54:1-28. [PubMed: 16280974]

Iglarz M, Touyz RM, Amiri F, Lavoie MF, Diep QN, Schiffrin EL. Effect of peroxisome proliferatoractivated receptor-alpha and -gamma activators on vascular remodeling in endothelin-dependent hypertension. Arterioscler Thromb Vasc Biol. 2003a; 23:45-51. [PubMed: 12524223]

Iglarz M, Touyz RM, Viel EC, Paradis P, Amiri F, Diep QN, et al. Peroxisome proliferator-activated receptor-alpha and receptor-gamma activators prevent cardiac fibrosis in mineralocorticoiddependent hypertension. Hypertension. 2003b; 42:737-743. [PubMed: 12860836]

Ikeda Y, Sugawara A, Taniyama Y, Uruno A, Igarashi K, Arima S, et al. Suppression of rat thromboxane synthase gene transcription by peroxisome proliferator-activated receptor gamma in macrophages via an interaction with NRF2. J Biol Chem. 2000; 275:33142-33150. [PubMed: 10930400]

Issemann I, Green S. Activation of a member of the steroid hormone receptor superfamily by peroxisome proliferators. Nature. 1990; 347:645-650. [PubMed: 2129546]

Jeffery TK, Morrell NW. Molecular and cellular basis of pulmonary vascular remodeling in pulmonary hypertension. Prog Cardiovasc Dis. 2002; 45:173-202. [PubMed: 12525995]

Jernigan NL, Walker BR, Resta TC. Endothelium-derived reactive oxygen species and endothelin-1 attenuate NO-dependent pulmonary vasodilation following chronic hypoxia. Am J Physiol Lung Cell Mol Physiol. 2004; 287:L801-L808. [PubMed: 15180921]

Kanki-Horimoto S, Horimoto H, Mieno S, Kishida K, Watanabe F, Furuya E, et al. Implantation of mesenchymal stem cells overexpressing endothelial nitric oxide synthase improves right ventricular impairments caused by pulmonary hypertension. Circulation. 2006; 114(1 Suppl):I181-I185. [PubMed: 16820570]

Kelly D, Campbell JI, King TP, Grant G, Jansson EA, Coutts AG, et al. Commensal anaerobic gut bacteria attenuate inflammation by regulating nuclear-cytoplasmic shuttling of PPAR-gamma and RelA. Nat Immunol. 2004; 5:104-112. [PubMed: 14691478]

Kodera Y, Takeyama K, Murayama A, Suzawa M, Masuhiro Y, Kato S. Ligand type-specific interactions of peroxisome proliferator-activated receptor gamma with transcriptional coactivators. J Biol Chem. 2000; 275:33201-33204. [PubMed: 10944516]

Konduri GG, Ou J, Shi Y, Pritchard KA Jr. Decreased association of HSP90 impairs endothelial nitric oxide synthase in fetal lambs with persistent pulmonary hypertension. Am J Physiol Heart Circ Physiol. 2003; 285:H204-H211. [PubMed: 12663260]

Kota BP, Huang TH, Roufogalis BD. An overview on biological mechanisms of PPARs. Pharmacol Res. 2005; 51:85-94. [PubMed: 15629253]

Kuzkaya N, Weissmann N, Harrison DG, Dikalov S. Interactions of peroxynitrite, tetrahydrobiopterin, ascorbic acid, and thiols: implications for uncoupling endothelial nitric-oxide synthase. J Biol Chem. 2003; 278:22546-22554. [PubMed: 12692136] 
Kwon J, Lee SR, Yang KS, Ahn Y, Kim YJ, Stadtman ER, et al. Reversible oxidation and inactivation of the tumor suppressor PTEN in cells stimulated with peptide growth factors. Proc Natl Acad Sci U S A. 2004; 101:16419-16424. [PubMed: 15534200]

Lambeth JD. Nox/Duox family of nicotin-amide adenine dinucleotide (phosphate) oxidases. Curr Opin Hematol. 2002; 9:11-17. [PubMed: 11753072]

Lambeth JD, Kawahara T, Diebold B. Regulation of Nox and Duox enzymatic activity and expression. Free Radic Biol Med. 2007; 43:319-331. [PubMed: 17602947]

Laudet V, Hanni C, Coll J, Catzeflis F, Stehelin D. Evolution of the nuclear receptor gene superfamily. EMBO J. 1992; 11:1003-1013. [PubMed: 1312460]

Law RE, Goetze S, Xi XP, Jackson S, Kawano Y, Demer L, et al. Expression and function of PPARgamma in rat and human vascular smooth muscle cells. Circulation. 2000; 101:1311-1318. [PubMed: 10725292]

Lee SR, Yang KS, Kwon J, Lee C, Jeong W, Rhee SG. Reversible inactivation of the tumor suppressor PTEN by H2O2. J Biol Chem. 2002; 277:20336-20342. [PubMed: 11916965]

Lepetit H, Eddahibi S, Fadel E, Frisdal E, Munaut C, Noel A, et al. Smooth muscle cell matrix metalloproteinases in idiopathic pulmonary arterial hypertension. Eur Respir J. 2005; 25:834-842. [PubMed: 15863640]

Leslie NR, Bennett D, Lindsay YE, Stewart H, Gray A, Downes CP. Redox regulation of PI 3-kinase signalling via inactivation of PTEN. Embo J. 2003; 22:5501-5510. [PubMed: 14532122]

Li H, Chen SJ, Chen YF, Meng QC, Durand J, Oparil S, et al. Enhanced endothelin-1 and endothelin receptor gene expression in chronic hypoxia. J Appl Physiol. 1994; 77:1451-1459. [PubMed: 7836152]

Lim H, Dey SK. A novel pathway of prostacyclin signaling-hanging out with nuclear receptors. Endocrinology. 2002; 143:3207-3210. [PubMed: 12193530]

Liu JQ, Zelko IN, Erbynn EM, Sham JS, Folz RJ. Hypoxic pulmonary hypertension: role of superoxide and NADPH oxidase (gp91phox). Am J Physiol Lung Cell Mol Physiol. 2006; 290:L2-L10. [PubMed: 16085672]

Macchia A, Marchioli R, Marfisi R, Scarano M, Levantesi G, Tavazzi L, et al. A meta-analysis of trials of pulmonary hypertension: a clinical condition looking for drugs and research methodology. Am Heart J. 2007; 153:1037-1047. [PubMed: 17540207]

Maehama T, Dixon JE. The tumor suppressor, PTEN/MMAC1, dephosphorylates the lipid second messenger, phosphatidylinositol 3,4,5-trisphosphate. J Biol Chem. 1998; 273:13375-13378. [PubMed: 9593664]

Makino N, Sugano M, Satoh S, Oyama J, Maeda T. Peroxisome proliferator-activated receptor-gamma ligands attenuate brain natriuretic peptide production and affect remodeling in cardiac fibroblasts in reoxygenation after hypoxia. Cell Biochem Biophys. 2006; 44:65-71. [PubMed: 16456235]

Martin-Nizard F, Furman C, Delerive P, Kandoussi A, Fruchart JC, Staels B, et al. Peroxisome proliferator-activated receptor activators inhibit oxidized low-density lipoprotein-induced endothelin-1 secretion in endothelial cells. J Cardiovasc Pharmacol. 2002; 40:822-831. [PubMed: 12451315]

Marx N, Schonbeck U, Lazar MA, Libby P, Plutzky J. Peroxisome proliferator-activated receptor gamma activators inhibit gene expression and migration in human vascular smooth muscle cells. Circ Res. 1998; 83:1097-1103. [PubMed: 9831704]

Matsuda Y, Hoshikawa Y, Ameshima S, Suzuki S, Okada Y, Tabata T, et al. Effects of peroxisome proliferator-activated receptor gamma ligands on monocrotaline-induced pulmonary hypertension in rats. Nihon Kokyuki Gakkai Zasshi. 2005; 43:283-288. [PubMed: 15969209]

McQuillan LP, Leung GK, Marsden PA, Kostyk SK, Kourembanas S. Hypoxia inhibits expression of eNOS via transcriptional and posttranscriptional mechanisms. Am J Physiol. 1994; 267:H1921H1927. [PubMed: 7526714]

Medoff BD, Okamoto Y, Leyton P, Weng M, Sandall BP, Raher MJ, et al. Adiponectin deficiency increases allergic airway inflammation and pulmonary vascular remodeling. Am J Respir Cell Mol Biol. 2009; 41:397-406. [PubMed: 19168697]

Mehta S, Stewart DJ, Langleben D, Levy RD. Short-term pulmonary vasodilation with L-arginine in pulmonary hypertension. Circulation. 1995; 92:1539-1545. [PubMed: 7664438] 
Mittal M, Roth M, Konig P, Hofmann S, Dony E, Goyal P, et al. Hypoxia-dependent regulation of nonphagocytic NADPH oxidase subunit NOX4 in the pulmonary vasculature. Circ Res. 2007; 101:258-267. [PubMed: 17585072]

Mizukami J, Taniguchi T. The antidiabetic agent thiazolidinedione stimulates the interaction between PPAR gamma and CBP. Biochem Biophys Res Commun. 1997; 240:61-64. [PubMed: 9367882]

Morrell NW, Adnot S, Archer SL, Dupuis J, Jones PL, MacLean MR, et al. Cellular and molecular basis of pulmonary arterial hypertension. J Am Coll Cardiol. 2009; 54(1 Suppl):S20-S31. [PubMed: 19555855]

Murata T, Hori M, Sakamoto K, Karaki H, Ozaki H. Dexamethasone blocks hypoxia-induced endothelial dysfunction in organ-cultured pulmonary arteries. Am J Respir Crit Care Med. 2004; 170:647-655. [PubMed: 15184203]

Murata T, Sato K, Hori M, Ozaki H, Karaki H. Decreased endothelial nitric-oxide synthase (eNOS) activity resulting from abnormal interaction between eNOS and its regulatory proteins in hypoxia-induced pulmonary hypertension. J Biol Chem. 2002; 277:44085-44092. [PubMed: 12185080]

Nagaya N, Kangawa K, Kanda M, Uematsu M, Horio T, Fukuyama N, et al. Hybrid cell-gene therapy for pulmonary hypertension based on phagocytosing action of endothelial progenitor cells. Circulation. 2003; 108:889-895. [PubMed: 12835224]

Nemenoff R, Meyer AM, Hudish TM, Mozer AB, Snee A, Narumiya S, et al. Prostacyclin prevents murine lung cancer independent of the membrane receptor by activation of peroxisomal proliferator-activated receptor gamma. Cancer Prev Res (Phila PA). 2008; 1:349-356.

Nisbet RE, Bland JM, Kleinhenz DJ, Mitchell PO, Walp ER, Sutliff RL, et al. Rosiglitazone attenuates chronic hypoxia-induced pulmonary hypertension in a mouse model. Am J Respir Cell Mol Biol. 2009; 42(4):482-490. [PubMed: 19520921]

Novotna J, Herget J. Possible role of matrix metalloproteinases in reconstruction of peripheral pulmonary arteries induced by hypoxia. Physiol Res. 2002; 51:323-334. [PubMed: 12449429]

Olefsky JM, Saltiel AR. PPAR gamma and the treatment of insulin resistance. Trends Endocrinol Metab. 2000; 11:362-368. [PubMed: 11042466]

Olschewski H, Rose F, Schermuly R, Ghofrani HA, Enke B, Olschewski A, et al. Prostacyclin and its analogues in the treatment of pulmonary hypertension. Pharmacol Ther. 2004; 102:139-153. [PubMed: 15163595]

Ozaki M, Kawashima S, Yamashita T, Ohashi Y, Rikitake Y, Inoue N, et al. Reduced hypoxic pulmonary vascular remodeling by nitric oxide from the endothelium. Hypertension. 2001; 37:322-327. [PubMed: 11230292]

Palmer RM, Ferrige AG, Moncada S. Nitric oxide release accounts for the biological activity of endothelium-derived relaxing factor. Nature. 1987; 327:524-526. [PubMed: 3495737]

Pascual G, Fong AL, Ogawa S, Gamliel A, Li AC, Perissi V, et al. A SUMOylation-dependent pathway mediates transrepression of inflammatory response genes by PPAR-gamma. Nature. 2005; 437:759-763. [PubMed: 16127449]

Patel L, Pass I, Coxon P, Downes CP, Smith SA, Macphee CH. Tumor suppressor and antiinflammatory actions of PPARgamma agonists are mediated via upregulation of PTEN. Curr Biol. 2001; 11:764-768. [PubMed: 11378386]

Peng Y, Liu H, Liu F, Liu Y, Li J, Chen X. Troglitazone inhibits synthesis of transforming growth factor-beta1 and reduces matrix production in human peritoneal mesothelial cells. Nephrology (Carlton). 2006; 11:516-523. [PubMed: 17199790]

Peredo HA, Mayer MA, Carranza A, Puyo AM. Pioglitazone and losartan modify hemodynamic and metabolic parameters and vascular prostanoids in fructose-overloaded rats. Clin Exp Hypertens. 2008; 30:159-169. [PubMed: 18293171]

Pistrosch F, Herbrig K, Oelschlaegel U, Richter S, Passauer J, Fischer S, et al. PPARgamma-agonist rosiglitazone increases number and migratory activity of cultured endothelial progenitor cells. Atherosclerosis. 2005; 183:163-167. [PubMed: 15907852]

Polikandriotis JA, Mazzella LJ, Rupnow HL, Hart CM. Peroxisome proliferator-activated receptor gamma ligands stimulate endothelial nitric oxide production through distinct peroxisome 
proliferator-activated receptor gamma-dependent mechanisms. Arterioscler Thromb Vasc Biol. 2005; 25:1810-1816. [PubMed: 16020752]

Pritchard KA Jr, Ackerman AW, Gross ER, Stepp DW, Shi Y, Fontana JT, et al. Heat shock protein 90 mediates the balance of nitric oxide and superoxide anion from endothelial nitric-oxide synthase. J Biol Chem. 2001; 276:17621-17624. [PubMed: 11278264]

Rabinovitch M. Molecular pathogenesis of pulmonary arterial hypertension. J Clin Invest. 2008; 118:2372-2379. [PubMed: 18596905]

Raines EW. PDGF and cardiovascular disease. Cytokine Growth Factor Rev. 2004; 15:237-254. [PubMed: 15207815]

Robbins IM, Morrow JD, Christman BW. Oxidant stress but not thromboxane decreases with epoprostenol therapy. Free Radic Biol Med. 2005; 38:568-574. [PubMed: 15683712]

Rosenkranz-Weiss P, Sessa WC, Milstien S, Kaufman S, Watson CA, Pober JS. Regulation of nitric oxide synthesis by proinflammatory cytokines in human umbilical vein endothelial cells. Elevations in tetrahydrobiopterin levels enhance endothelial nitric oxide synthase specific activity. J Clin Invest. 1994; 93:2236-2243. [PubMed: 7514193]

Rosenzweig A. Circulating endothelial progenitors - cells as biomarkers. N Engl J Med. 2005; 353:1055-1057. [PubMed: 16148292]

Sakai S, Miyauchi T, Irukayama-Tomobe Y, Ogata T, Goto K, Yamaguchi I. Peroxisome proliferatoractivated receptor-gamma activators inhibit endothelin-1-related cardiac hypertrophy in rats. Clin Sci (Lond). 2002; 103(Suppl 48):16S-20S. [PubMed: 12193046]

Sanchez O, Marcos E, Perros F, Fadel E, Tu L, Humbert M, et al. Role of endothelium-derived CC chemokine ligand 2 in idiopathic pulmonary arterial hypertension. Am J Respir Crit Care Med. 2007; 176:1041-1047. [PubMed: 17823354]

Sandirasegarane L, Charles R, Bourbon N, Kester M. NO regulates PDGF-induced activation of PKB but not ERK in A7r5 cells: implications for vascular growth arrest. Am J Physiol Cell Physiol. 2000; 279:C225-C235. [PubMed: 10898734]

Sata M. Role of circulating vascular progenitors in angiogenesis, vascular healing, and pulmonary hypertension: lessons from animal models. Arterioscler Thromb Vasc Biol. 2006; 26:1008-1014. [PubMed: 16456096]

Satoh K, Kagaya Y, Nakano M, Ito Y, Ohta J, Tada H, et al. Important role of endogenous erythropoietin system in recruitment of endothelial progenitor cells in hypoxia-induced pulmonary hypertension in mice. Circulation. 2006; 113:1442-1450. [PubMed: 16534010]

Schermuly RT, Dony E, Ghofrani HA, Pullamsetti S, Savai R, Roth M, et al. Reversal of experimental pulmonary hypertension by PDGF inhibition. J Clin Invest. 2005; 115:2811-2821. [PubMed: 16200212]

Schwartzbauer G, Robbins J. The tumor suppressor gene PTEN can regulate cardiac hypertrophy and survival. J Biol Chem. 2001; 276:35786-35793. [PubMed: 11448956]

Serrander L, Cartier L, Bedard K, Banfi B, Lardy B, Plastre O, et al. NOX4 activity is determined by mRNA levels and reveals a unique pattern of ROS generation. Biochem J. 2007; 406:105-114. [PubMed: 17501721]

Sessa WC, Garcia-Cardena G, Liu J, Keh A, Pollock JS, Bradley J, et al. The Golgi association of endothelial nitric oxide synthase is necessary for the efficient synthesis of nitric oxide. J Biol Chem. 1995; 270:17641-17644. [PubMed: 7543089]

Simonneau G, Robbins IM, Beghetti M, Channick RN, Delcroix M, Denton CP, et al. Updated clinical classification of pulmonary hypertension. J Am Coll Cardiol. 2009; 54(1 Suppl):S43-S54. [PubMed: 19555858]

Sorescu D, Weiss D, Lassegue B, Clempus RE, Szocs K, Sorescu GP, et al. Superoxide production and expression of nox family proteins in human atherosclerosis. Circulation. 2002; 105:1429-1435. [PubMed: 11914250]

Sorescu GP, Song H, Tressel SL, Hwang J, Dikalov S, Smith DA, et al. Bone morphogenic protein 4 produced in endothelial cells by oscillatory shear stress induces monocyte adhesion by stimulating reactive oxygen species production from a nox1-based NADPH oxidase. Circ Res. 2004; 95:773-779. [PubMed: 15388638] 
Steinhorn RH, Russell JA, Lakshminrusimha S, Gugino SF, Black SM, Fineman JR. Altered endothelium-dependent relaxations in lambs with high pulmonary blood flow and pulmonary hypertension. Am J Physiol Heart Circ Physiol. 2001; 280:H311-H317. [PubMed: 11123246]

Stenmark KR, Fagan KA, Frid MG. Hypoxia-induced pulmonary vascular remodeling: cellular and molecular mechanisms. Circ Res. 2006; 99:675-691. [PubMed: 17008597]

Stenmark KR, Meyrick B, Galie N, Mooi WJ, McMurtry IF. Animal models of pulmonary arterial hypertension: the hope for etiological discovery and pharmacological cure. Am J Physiol Lung Cell Mol Physiol. 2009; 297:L1013-L1032. [PubMed: 19748998]

Subbaramaiah K, Lin DT, Hart JC, Dannenberg AJ. Peroxisome proliferator-activated receptor gamma ligands suppress the transcriptional activation of cyclooxygenase-2. Evidence for involvement of activator protein-1 and CREB-binding protein/p300. J Biol Chem. 2001; 276:12440-12448. [PubMed: 11278336]

Sugawara A, Uruno A, Kudo M, Ikeda Y, Sato K, Taniyama Y, et al. Transcription suppression of thromboxane receptor gene by peroxisome proliferator-activated receptor-gamma via an interaction with Sp1 in vascular smooth muscle cells. J Biol Chem. 2002; 277:9676-9683. [PubMed: 11777901]

Summer R, Fiack CA, Ikeda Y, Sato K, Dwyer D, Ouchi N, et al. Adiponectin deficiency: a model of pulmonary hypertension associated with pulmonary vascular disease. Am J Physiol Lung Cell Mol Physiol. 2009; 297:L432-L438. [PubMed: 19561137]

Szanto A, Nagy L. The many faces of PPARgamma: anti-inflammatory by any means? Immunobiology. 2008; 213:789-803. [PubMed: 18926294]

Tallquist M, Kazlauskas A. PDGF signaling in cells and mice. Cytokine Growth Factor Rev. 2004; 15:205-213. [PubMed: 15207812]

Tesse A, Al-Massarani G, Wangensteen R, Reitenbach S, Martinez MC, Andriantsitohaina R. Rosiglitazone, a peroxisome proliferator-activated receptor-gamma agonist, prevents microparticle-induced vascular hyporeactivity through the regulation of proinflammatory proteins. J Pharmacol Exp Ther. 2008; 324:539-547. [PubMed: 18039959]

Tong H, Chen W, Steenbergen C, Murphy E. Ischemic preconditioning activates phosphatidylinositol-3-kinase upstream of protein kinase C. Circ Res. 2000; 87:309-315. [PubMed: 10948065]

Tontonoz P, Hu E, Graves RA, Budavari AI, Spiegelman BM. mPPAR gamma 2: tissue-specific regulator of an adipocyte enhancer. Genes Dev. 1994; 8:1224-1234. [PubMed: 7926726]

Tuder RM, Cool CD, Geraci MW, Wang J, Abman SH, Wright L, et al. Prostacyclin synthase expression is decreased in lungs from patients with severe pulmonary hypertension. Am J Respir Crit Care Med. 1999; 159:1925-1932. [PubMed: 10351941]

Tuder RM, Groves B, Badesch DB, Voelkel NF. Exuberant endothelial cell growth and elements of inflammation are present in plexiform lesions of pulmonary hypertension. Am J Pathol. 1994; 144:275-285. [PubMed: 7508683]

Tuder RM, Voelkel NF. Pulmonary hypertension and inflammation. J Lab Clin Med. 1998; 132:16-24. [PubMed: 9665367]

Wang CH, Ciliberti N, Li SH, Szmitko PE, Weisel RD, Fedak PW, et al. Rosiglitazone facilitates angiogenic progenitor cell differentiation toward endothelial lineage: a new paradigm in glitazone pleiotropy. Circulation. 2004; 109:1392-1400. [PubMed: 14993120]

Wang Q, Zhou Y, Wang X, Chung DH, Evers BM. Regulation of PTEN expression in intestinal epithelial cells by c-Jun NH2-terminal kinase activation and nuclear factor-kappaB inhibition. Cancer Res. 2007; 67:7773-7781. [PubMed: 17699782]

Wang TD, Chen WJ, Cheng WC, Lin JW, Chen MF, Lee YT. Relation of improvement in endothelium-dependent flow-mediated vasodilation after rosiglitazone to changes in asymmetric dimethylarginine, endothelin-1, and C-reactive protein in nondiabetic patients with the metabolic syndrome. Am J Cardiol. 2006; 98:1057-1062. [PubMed: 17027571]

Werner N, Kosiol S, Schiegl T, Ahlers P, Walenta K, Link A, et al. Circulating endothelial progenitor cells and cardiovascular outcomes. N Engl J Med. 2005; 353:999-1007. [PubMed: 16148285]

Wohlfert EA, Nichols FC, Nevius E, Clark RB. Peroxisome proliferator-activated receptor gamma (PPARgamma) and immunoregulation: enhancement of regulatory T cells through PPARgamma- 
dependent and -independent mechanisms. J Immunol. 2007; 178:4129-4135. [PubMed: 17371968]

Xue C, Johns RA. Endothelial nitric oxide synthase in the lungs of patients with pulmonary hypertension. N Engl J Med. 1995; 333:1642-1644. [PubMed: 7477212]

Zaidi SH, You XM, Ciura S, Husain M, Rabinovitch M. Overexpression of the serine elastase inhibitor elafin protects transgenic mice from hypoxic pulmonary hypertension. Circulation. 2002; 105:516-521. [PubMed: 11815437]

Zhang L, Sheppard OR, Shah AM, Brewer AC. Positive regulation of the NADPH oxidase NOX4 promoter in vascular smooth muscle cells by E2F. Free Radic Biol Med. 2008; 45:679-685. [PubMed: 18554521]

Zhao YD, Courtman DW, Ng DS, Robb MJ, Deng YP, Trogadis J, et al. Microvascular regeneration in established pulmonary hypertension by angiogenic gene transfer. Am J Respir Cell Mol Biol. 2006; 35:182-189. [PubMed: 16543611]

Zhu Y, Kan L, Qi C, Kanwar YS, Yeldandi AV, Rao MS, et al. Isolation and characterization of peroxisome proliferator-activated receptor (PPAR) interacting protein (PRIP) as a coactivator for PPAR. J Biol Chem. 2000; 275:13510-13516. [PubMed: 10788465] 

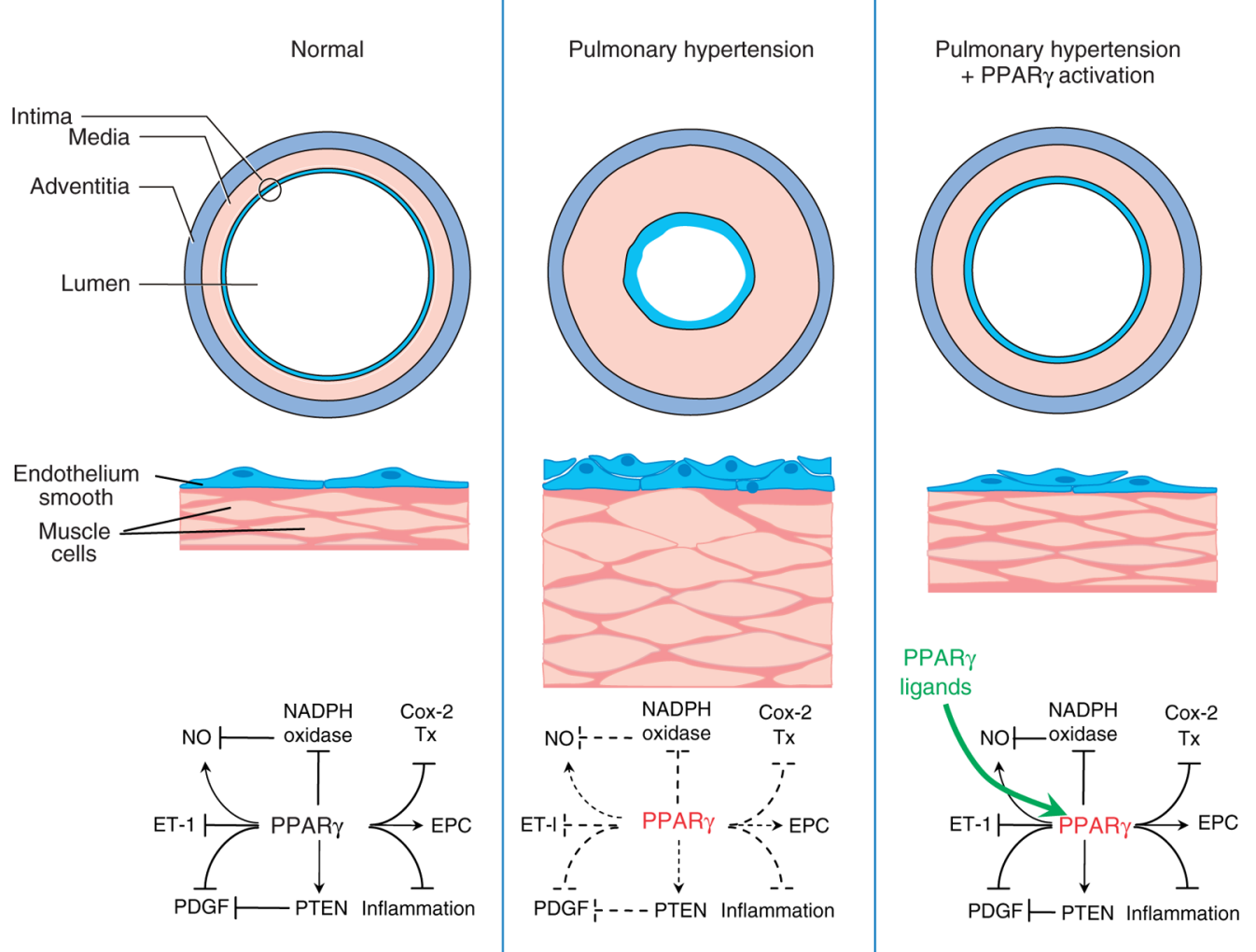

Figure 1.

Putative pathways by which PPAR $\gamma$ participates in pulmonary hypertension pathogenesis and therapy. As illustrated in the left panel, under normal circumstances, current evidence indicates that PPAR $\gamma$ stimulates $(\rightarrow)$ or inhibits $(-)$ several pathways involved in pulmonary hypertension pathogenesis including inhibition of NADPH oxidase and stimulation of endothelial nitric oxide (NO), effects that collectively enhance NO bioavailability. PPAR $\gamma$ can also inhibit endothelin-1 (ET-1) and platelet-derived growth factor (PDGF) signaling, stimulate phosphatase and tensin homolog deleted on chromosome 10 (PTEN) expression, inhibit inflammation and Cox-2 expression as well as thromboxane (Tx) production, and stimulate endothelial progenitor cell (EPC) activity. As shown in the middle panel, reduced PPAR $\gamma$ expression (red text) can promote pulmonary hypertension through abnormal proliferation of endothelial and smooth muscle cells resulting in intimal and medial proliferation and thickening that reduces the vascular lumen and increases pulmonary vascular resistance. The mechanisms for abnormal pulmonary vascular cell proliferation may relate to the effects of impaired PPAR $\gamma$ signaling (dashed lines). As depicted in the right panel, PPAR $\gamma$ ligands (green) and activation of the PPAR $\gamma$ receptor can normalize $\operatorname{PPAR} \gamma$ signaling to attenuate or reverse endothelial dysfunction, abnormal cell proliferation, and pulmonary vascular remodeling. 
Table 1

Pathways implicated in PH pathogenesis and the effects of PPAR $\gamma$ activation.

\begin{tabular}{|ll|}
\hline Mechanism of PH & Effects of PPAR $\gamma$ activation \\
\hline Vasoconstrictor/vasodilator imbalance & \\
a) Decreased prostacyclin & Regulation of prostanoid production [Subbaramaiah et al. 2001] \\
b) Decreased NO & Increase NO production [Calnek et al. 2003] and reduced superoxide generation \\
& [Hwang et al. 2005] \\
c) Increased ET-1 & Inhibit endothelial cell ET-1 secretion [Liu et al. 2006; Martin-Nizard et al. 2002; \\
& Fukunaga et al. 2001; Delerive et al. 1999] \\
d) Increased thromboxane A 2 & Suppression of thromboxane synthase [Ikeda et al. 2000] and thromboxane receptor \\
& expression [Coyle and Kinsella, 2006; Sugawara et al. 2002] \\
Vascular remodeling & \\
a) Increased VSMC proliferation & c-kit staining [Crossno et al. 2007] \\
b) Increased extracellular matrix proteins & Decreased collagen production and elastin deposition [Crossno et al. 2007] \\
c) Increased muscularization & Decreased alpha actin staining in PH models [Nisbet et al. 2009; Crossno et al. 2007; \\
Inflammation & Hansmann et al. 2007] \\
a) Migration of inflammatory cells into vessel & \\
wall & Reduced inflammatory response [Szanto and Nagy, 2008] \\
Endothelial progenitor cells & \\
a) Impaired migration of EPCs to vasculature & Facilitate differentiation and increase number and migratory activity [Gensch et al. \\
\hline
\end{tabular}

PH, pulmonary hypertension; PPAR $\gamma$, peroxisome proliferator-activated receptor gamma; NO, nitric oxide; ET-1, endothelin-1; VSMC, vascular smooth muscle cell; EPC, endothelial progenitor cell. 